\title{
O Seminário Católico e a Formação SACERdotal: um Estudo Psicossocial ${ }^{1}$
}

\author{
Sílvio José Benelli² \\ Instituto de Psicologia-USP
}

\begin{abstract}
Nesta pesquisa realizamos uma análise institucional, cujo objetivo é problematizar as práticas formativas eclesiásticas católicas, tais como elas se apresentam nos modos de funcionamento institucional de um seminário católico e no registro do saber eclesiástico, como produtoras de uma modalidade específica da subjetividade (futuros padres). Por meio da observação do cotidiano do estabelecimento, de entrevistas semi-estruturadas com diferentes atores institucionais, da análise dos documentos oficiais do Magistério católico e de uma revisão bibliográfica pertinente, buscamos compreender as relações de formação entre padres formadores e seminaristas em termos de um dispositivo privilegiado de constituição do seminário como agência de produção de subjetividade. Concluímos que o seminário investigado pode ser considerado uma instituição tipicamente disciplinar cujo principal mecanismo e operador microfísico é o relatório (instrumento de exame, vigilância e sanção normalizadora).
\end{abstract}

Descritores: Psicologia e religião. Análise institucional. Seminários. Subjetividade. Seminaristas. Catolicismo.

1 Este artigo é parte da pesquisa de mestrado intitulada "Pescadores de Homens: a produção da subjetividade no contexto institucional de um seminário católico”, desenvolvida pelo autor, sob orientação de Abílio da Costa-Rosa, no Curso de pós-graduação em Psicologia da Faculdade de Ciências e Letras, UNESP, Assis, S.P., com financiamento da FAPESP.

2 Psicólogo, doutorando em Psicologia Social pelo Instituto de Psicologia - USP, bolsista da CAPES. Endereço eletrônico: sjbewelli@yahoo.com.br 


\section{A produção de subjetividade no contexto institucional de um seminário católico}

$\mathrm{O}$ cristianismo é uma religião que se institucionalizou ao longo da história e assumiu a forma de uma instituição denominada Igreja católica, desenvolvendo uma forma de governo hierárquico, legislação própria, doutrina e pensamento teológico originais (Beozzo, 1993). O governo da Igreja católica é conduzido pelo Papa e pelos bispos, sucessores dos apóstolos que inicialmente seguiram Jesus Cristo (Igreja Católica, 1982, 1992). Os presbíteros, sacerdotes seculares ou padres diocesanos são os ministros ordenados que trabalham como colaboradores diretos dos bispos diocesanos. Uma diocese é um território geográfico delimitado que tem existência assegurada e regulamentada pela legislação canônica eclesiástica. O Código de Direito Canônico (Igreja Católica, 1983) é o conjunto das leis constitucionais da Igreja católica. Cada diocese tem um bispo, responsável por sua administração pastoral, e está dividida em paróquias, as quais são administradas por um padre diocesano que, geralmente, vive sozinho e é uma figura importante, pois desempenha a função de líder comunitário, sobretudo, nas cidades do interior.

O Papa, os bispos, os padres e os diáconos são os membros ordenados que pertencem à hierarquia da Igreja católica. Além da hierarquia, dela fazem parte todos os batizados que aderem à fé em Jesus, que podem ser solteiros, casados, viúvos e os que vivem como "religiosos". Os religiosos se organizam como "congregações" independentes da autoridade dos bispos diocesanos, fazem votos de pobreza, castidade e obediência e vivem em comunidade, não estão limitados por um espaço geográfico específico e espalham-se por todas as dioceses.

A palavra ordem ou ordenação era usada no império romano para designar a nomeação de um funcionário imperial. Desde a época de Constantino, na primeira metade do século IV d.C., os bispos, padres diocesanos e diáconos começaram a formar parte dos funcionários do império, passando a utilizar títulos e distintivos próprios para significar seus cargos, como, por exemplo, a estola. A ordenação é o rito pelo qual a Igreja promove um de seus membros a um determinado grau do ministério eclesial: diaconato, presbiterato ou episcopado. Toda a autoridade que os ordenados recebem deve ser colocada a serviço da comunidade cristã; eles existem desde o começo dessas comunidades e se ocupam de diversas tarefas. Atualmente, a Igreja Católica continua promoven- 
do determinadas pessoas para o ministério ordenado, mediante o sacramento da ordem sacerdotal.

O candidato à ordem sacerdotal, o seminarista, tem um longo percurso de formação teórica e prática, humana e espiritual, que se realiza nos chamados seminários diocesanos (Brandão, 1984; Finkler, 1990; Giordani, 1990; Moro, 1997). Deve concluir os estudos do $2^{\circ}$ grau, cursar três anos de Filosofia e quatro anos de Teologia no seminário maior, processo que pode durar mais ou menos tempo, dependendo da etapa escolar na qual o candidato se encontra. Mas concluído o $2^{\circ}$ grau, ele ainda tem pelo menos mais sete anos de formação. Também existem os seminários menores, onde os candidatos podem permanecer enquanto concluem o $2^{\circ}$ grau. Assim, um candidato à ordem sacerdotal precisa de mais ou menos oito anos para se formar e ser ordenado.

Nesta pesquisa, procuramos observar como se dá a vida dos seminaristas no contexto social da instituição na qual permanecem durante a realização de sua formação filosófica. Vivem em comunidade, moram, estudam e se divertem juntos e no mesmo espaço físico, tendo uma vida de internados, com maior ou menor contato com a realidade externa. Seu tempo é programado de modo uniforme pela equipe dirigente (os formadores), aos quais devem obediência e que são os representantes indicados pelos bispos para administrarem o seminário provincial. Em sua formação, durante os anos de estudos em que vive no seminário, o indivíduo se torna seminarista e passa por uma modelagem institucional de sua subjetividade.

Partimos da hipótese de que este seminário católico, como uma casa de formação de pessoas, pode ser considerado uma instituição total (Goffman, 1987) e entendemos que esse espaço social específico merece uma investigação, considerando-se que prepara candidatos à ordem sacerdotal. Queremos conhecer quais são seus procedimentos formativos, desde que esta instituição recebe um número razoável de indivíduos todos os anos, formando-os para liderar uma grande massa de pessoas que vivem nas suas futuras paróquias. Pois o padre diocesano ocupa um lugar social importante no comando dessas comunidades, orientando-as e exercendo grande influência sobre elas.

A partir da contribuição de Foucault (1999a), investigamos o seminário como um estabelecimento que encarna o poder disciplinar e as práticas disciplinares que esse poder implementa, procurando detectar como são os sujei- 
tos que seu funcionamento microfísico produz. As relações de formação entre formadores e seminaristas são focalizadas como um dispositivo privilegiado de constituição do seminário, enquanto agência de produção de subjetividade. À luz das contribuições desse autor, nossos dados revelaram diversas características e nuances do seminário, permitindo compreendê-lo como dispositivo organizado de modelagem subjetiva, tanto por seus discursos e por suas práticas, quanto pela articulação (sintonia ou contradição) desses dois aspectos. Ao mesmo tempo, podemos aspirar a compreender, com maior desenvoltura, as características da subjetividade aí produzida e suas possíveis implicações para a performance social dos padres como sujeitos emergentes desse processo institucional.

Pouco se sabe, no meio acadêmico, a respeito dessa realidade. Um caminho para lidar com essa dificuldade é uma produção científica que ofereça um maior conhecimento da subjetividade que se produz e se desenvolve nesse ambiente social e institucional específico. Este artigo é uma síntese de nossa pesquisa de mestrado, cujo objetivo é problematizar as práticas formativas eclesiásticas católicas, tais como elas se apresentam nos modos de funcionamento institucionais do seminário católico e no registro do saber eclesiástico, enquanto produtoras de uma possível subjetividade eclesiástica (futuros padres).

A formação sacerdotal, a produção do padre católico (que entendemos como produção de subjetividade), é um processo que acontece no bojo de uma conjuntura social e eclesial específica. Ela se processa particularmente no âmbito do seminário, estabelecimento fechado, criado pela Igreja católica para preparar os membros da hierarquia clerical. Escutar os discursos que circulam no estabelecimento e procurar detectar quais são as práticas predominantes no processo formativo são aspectos importantes para se estudar a produção de subjetividade no seminário católico. Se pudermos ouvir esses discursos, captar as práticas desenvolvidas no contexto institucional de um seminário católico e olhar também para o contexto global, então, talvez, possamos entender o que é essa instituição e o que ela pode produzir nas atuais circunstâncias. A partir de um diagnóstico institucional, se houver demanda, será possível pensar em estratégias políticas que visem à transformação dessa realidade.

Muitas questões pedagógicas, psicológicas, psiquiátricas, hospitalares, de saúde coletiva etc., podem se tornar mais inteligíveis quando inseridas num 
marco institucional global. Entendemos que os problemas institucionais são também problemas sociais e soluções técnicas, muitas vezes, não são suficientes para resolvê-los, pois exigem soluções políticas para sua metabolização. A política não é meramente nem uma questão técnica (eficácia administrativa) nem científica (conhecimentos especializados sobre gerenciamento ou administração), é ação e decisão coletiva quanto aos interesses e direitos do próprio grupo social (Benelli, 2004). Um estudo do funcionamento institucional e dos diversos fenômenos que se produzem nesse espaço social específico pode proporcionar indícios valiosos quanto aos procedimentos utilizados na formação de pessoas. Seria possível entender como nessas instituições se produz e reproduz a subjetividade daqueles que as compõem, tanto internados quanto dirigentes.

O seminário católico, sendo uma instituição dedicada à formação de novos membros do clero, tem características peculiares em relação aos demais estabelecimentos do gênero. Seu funcionamento prevê que seus internados se tornarão padres, passando de internado/seminarista/formando a dirigente/padre/formador. O seminário produz padres, que são agentes formados e que se tornam, por sua vez, agentes formadores. Por outro lado, no mais comum de seus resultados, produz padres que ocuparão lugares proeminentes na liderança de setores relevantes das comunidades. Pensamos que uma hipótese pertinente é que seu processo formativo tem uma incidência direta no tipo de prática social desenvolvida por esses agentes. Para entender melhor esse ator social que tem sua relevância no meio social, precisamos inicialmente nos debruçar sobre a instituição seminário, estudá-la e produzir um conhecimento a seu respeito.

Ir ao encontro da subjetividade institucional do seminarista é uma tentativa de produzir uma pesquisa mais próxima da realidade social brasileira, e que possa também vir a contribuir com um saber mais específico sobre a subjetividade no contexto brasileiro. Pensamos, ao mesmo tempo, estar em sintonia com os estudos que investigam como se produzem os atravessamentos da subjetividade, em geral, no mundo contemporâneo. 


\section{As instituições totais e seus mecanismos produtores de subjetividade}

Goffman (1987) demonstra que há mais coisas em comum entre uma prisão e um convento, um asilo de loucos e um campo de concentração, entre um navio em alto mar e um internato escolar, do que parece à primeira vista. Todos estes estabelecimentos utilizam mecanismos de segregação, estratificação social e modelagem da subjetividade, alternando punições, recompensas e a estratégia de dividir para reinar, que não são necessariamente diferentes das relações de dominação e subjetivação, dos processos de poder em vigor em toda e qualquer sociedade. Mas, nestes estabelecimentos, os mecanismos produtores de subjetividade são exacerbados, por se tratar de situações extremas. De certa forma, são estabelecimentos específicos e como que purificados, revelando as engrenagens do poder de modo mais explícito e evidente, próprias para a pesquisa em laboratório.

As análises de Goffman (1987) nos apresentam os procedimentos estruturados para a modelagem subjetiva e formas de repressão específicas que são efetuadas dentro dos muros das instituições totalitárias. Também nos revela que formas de repressão mais gerais se dão na sociedade de massas, produzindo efeitos terríveis sobre indivíduos e categorias sociais inteiras.

Partindo dessa pesquisa de campo e utilizando uma ampla bibliografia, Goffman (1987) elaborou o conceito de "instituição total", caracterizando-a pelo seu "fechamento" através de barreiras, que são levantadas para segregar os internados do contato social com o mundo exterior. As proibições à saída estão muitas vezes incluídas no plano físico e arquitetônico da mesma. Seu traço principal é que ela concentra todos os diferentes aspectos da vida de uma pessoa (trabalho, lazer, descanso) no mesmo local e sob a autoridade de uma equipe dirigente.

As instituições totais podem ser enumeradas em cinco categorias: a) para cuidar de pessoas que são consideradas incapazes e inofensivas, tais como as casas de cegos, asilos para idosos, órfãos e indigentes; b) para cuidar de pessoas consideradas incapazes de cuidar de si mesmas e que são também uma ameaça não intencional para a comunidade, como por exemplo, sanatórios para tuberculosos, hospitais para doentes mentais e leprosários; c) para proteger a comunidade contra ameaças e perigos intencionais, sem se importar 
muito com o bem-estar das pessoas segregadas, onde se inserem as cadeias, penitenciárias, campos de prisioneiros de guerra e campos de concentração; d) para realizar de um modo mais adequado alguma tarefa instrumental, tais como: quartéis, navios, colégios internos, campos de trabalho, colônias; e) para servir de refúgio do mundo, que também podem servir como locais de instrução para religiosos, tais como: abadias, mosteiros, conventos e outros claustros. Esta classificação não pretende ser completa, nem totalmente clara, nem definitiva. É possível traçar um perfil geral a partir dessa lista de instituições, mas esse esquema não parece ser exclusivo delas e nem todos os traços se aplicam a todas elas.

A instituição total é um híbrido social, constituído parcialmente como grupo residencial e parcialmente como organização formal, sendo um viveiro ou uma estufa que funciona como instrumento para modelar, mudar e transformar pessoas. Cada instituição total é, assim, um experimento natural do que se pode fazer com a identidade de um indivíduo e é aí que reside seu interesse para a Psicologia, que se ocupa com o estudo da Subjetividade e da Saúde Coletiva.

Contudo, sentimos a ausência de um campo no qual situar as análises de Goffman que nos permitisse localizar as "instituições totais" dentro de uma evolução geral das instituições. Esse campo de referências históricas que falta em seu pensamento, nós o encontramos na obra de Michel Foucault, no que se refere a uma história do desenvolvimento das instituições que, no passado, se ocupavam com presos, loucos, estudantes e doentes (Foucault, 1984b, 1999b).

\section{Michel Foucault e as instituições disciplinares}

Segundo Foucault (1984b), a sociedade disciplinar surgiu por volta do século XVIII, caracterizando-se, sobretudo, como um modo de organizar o espaço, de controlar o tempo, de vigiar e registrar continuamente o indivíduo e sua conduta. A sociedade disciplinar deu lugar ao nascimento de determinados saberes (ciências humanas), nos quais o modelo prioritário de estabelecimento da verdade é o exame. Por meio desse procedimento, instaurou-se um modo de poder no qual a sujeição não se faz apenas sob a forma negativa da repressão, mas, principalmente, sob a forma mais sutil do adestramento, numa produção 
positiva de comportamentos que definem o homem enquanto "indivíduo" e o que ele pode e deve ser, segundo critérios da "normalidade".

Ao mesmo tempo em que surgiram esse saberes e poderes disciplinares, instalaram-se no mundo contemporâneo algumas instituições específicas a eles articuladas. Essas instituições que surgiram por volta do início do século XIX se encarnaram nas fábricas, hospitais, escolas, casas de correção, prisões, manicômios etc., que, ainda hoje, mantém características de fundo idênticas: a manutenção da vigilância através da visibilidade. Recluem o indivíduo, não propriamente para excluí-lo, mas para incluí-lo num sistema normalizador.

Estas instituições têm como funções o controle do tempo, dos corpos e a instalação de um poder polimorfo. Fazem funcionar um poder polivalente, microfísico, que não é essencialmente localizável em um pólo centralizado e personalizado, mas que é, principalmente, difuso, espalhado, minucioso, capilar.

Quando Foucault analisa o poder, ele o estuda visando a explicitar, por meio de análises minuciosas e precisas de práticas políticas disciplinares, como uma determinada sociedade produz o sujeito como individualidade. Apesar de Foucault ter dedicado sua atenção ao que atualmente chamamos de análise das instituições, não limitou suas pesquisas ao estudo das mesmas, preferindo privilegiar o desenvolvimento das tecnologias de poder. É preciso analisar as instituições a partir das relações de poder.

Em Vigiar e Punir, Foucault (1999b) não faz a história das diversas instituições disciplinares. O objetivo de sua análise teria sido o de localizar algumas das técnicas essenciais que, de uma instituição à outra, se generalizaram mais facilmente, técnicas essas que definem um certo modo de investimento político do corpo e que, a partir do século XVIII, acabaram por cobrir todo o corpo social (Foucault, 1999b, p. 117). Essas técnicas de dominação intervêm materialmente, investindo na realidade mais concreta dos indivíduos: seu corpo.

A "microfísica" do poder analisa esses procedimentos técnicos do poder que realizam um controle detalhado, minucioso, do corpo: dos gestos, das atitudes, dos comportamentos, dos hábitos. Essas técnicas que realizam a sujeição constante das forças do corpo e que impõem uma relação de docilidadeutilidade são chamadas de disciplinas ou poder disciplinar. 
Foucault (1999a) afirma que o poder disciplinar produz, a partir dos corpos que controla, uma individualidade dotada de quatro características: essa individualidade é celular (pelo jogo da repartição espacial), é orgânica (pela codificação das atividades), é genética (pela seriação do tempo) e é combinatória (pela composição das forças). Para produzir essa individualidade, o poder disciplinar utiliza quatro grandes técnicas: constrói espaços funcionais e hierárquicos (trata-se de uma técnica de distribuição dos indivíduos por meio da inserção dos corpos em um espaço individualizado, mas as relações de poder disciplinar não exigem necessariamente um espaço fechado para se realizarem); prescreve manobras (trata-se de uma codificação instrumental do corpo que estabelece a sujeição do corpo ao tempo); impõe exercícios (trata-se de uma técnica pela qual se impõe aos corpos tarefas ao mesmo tempo repetitivas e diferentes, mas sempre graduadas); e organiza "táticas" (trata-se de uma técnica que permite a inserção do corpo singular em todo um conjunto com o qual se articula e que permite, também, a combinação cuidadosamente medida das forças, exigindo para tal finalidade um sistema preciso de comando).

A eficácia do poder disciplinar resultaria do uso de três instrumentos simples: a vigilância hierárquica, a sanção normalizadora e o exame que combina os traços da hierarquia que vigia com os da sanção que normaliza. $\mathrm{O}$ exame, como controle normalizante e vigilância que permite qualificar, classificar e punir,

está no centro dos processos que constituem o indivíduo como efeito e objeto de poder, como efeito e objeto de saber. É ele que realiza as grandes funções disciplinares de repartição e classificação, de extração máxima das forças e do tempo, de acumulação genética contínua, de composição ótima das aptidões. Portanto, de fabricação da individualidade celular, orgânica, genética e combinatória. Com ele se ritualizam aquelas disciplinas que se pode caracterizar com uma palavra, dizendo que são uma modalidade de poder para o qual a diferença individual é pertinente (Foucault, 1999b, p. 160).

Não é todo tipo de poder que individualiza, mas apenas um tipo específico que Foucault denominou de disciplinar.

Parece que Goffman tem uma percepção apenas repressiva do poder, enquanto que Foucault apresenta o poder como portador de uma positividade produtiva, tanto de saberes quanto de sujeitos. Neste último, encontramos 
também uma história dos diferentes modos de subjetivação em nossa cultura, (Foucault, 1982, 1984a, 1985). Mas, quanto a esse tema, faremos apenas algumas indicações, na conclusão do trabalho, pertinentes para um desdobramento futuro desta pesquisa, no qual poderíamos pensar no atravessamento microfísico do seminário.

\section{Caracterização dos sujeitos da pesquisa: o estabelecimento seminário e os} atores institucionais

O seminário católico que pesquisamos funciona em regime de internato, no qual mais de 80 seminaristas estudam Filosofia durante 3 anos, numa etapa preparatória inicial para o sacerdócio. Pesquisamos o funcionamento da vida institucional por meio de visitas de observação participante e utilizamos entrevistas semidirigidas para entender como o seminarista experiencia sua vida no contexto institucional. Entrevistamos, também, os membros da equipe dirigente da instituição. Realizamos um estudo do registro do saber eclesiástico relativo à formação do sacerdote católico (sistema de regras produzidos pelo Magistério da Igreja Católica, consignados em documentos oficiais que regem a formação sacerdotal). Supomos que a cultura eclesiástica católica determina processos de subjetivação de acordo com seu próprio sistema de regras (Benelli, 2003c).

Os dados obtidos por meio da observação participante foram sistematizados em categorias analíticas e, os das entrevistas, foram tratados a partir da metodologia de análise do discurso do sujeito coletivo (Lefèvre, 2000). Nossa análise inicial foi pautada no contexto teórico elaborado por Goffman (1987) para o estudo das instituições totais e dos efeitos de suas práticas na vida e na subjetividade. Ampliamos nossa pesquisa, utilizando, para tanto, a contribuição de Foucault (1982, 1984b, 1999a, 1999b): procuramos investigar o seminário filosófico como um estabelecimento que encarna o poder disciplinar e a tecnologia que esse poder implementa. Buscamos detectar como são os sujeitos que seu funcionamento microfísico produz, focalizando as relações de formação entre formadores e seminaristas como um dispositivo privilegiado de constituição do seminário, enquanto agência de produção de subjetividade. 
Como mediação e pano de fundo para nossos objetivos, examinamos o processo histórico que engendrou a atual sociedade disciplinar, como um projeto do Estado de normalização social, e possibilitou o aparecimento das instituições totalitárias, que se atualizam em estabelecimentos tais como o seminário católico. Realizamos, também, algumas incursões literárias: procuramos estudar o funcionamento microfísico do poder no hospital psiquiátrico (Benelli \& Costa-Rosa, 2003) e no colégio interno (Benelli, 2002, 2003a, 2003b).

\section{As práticas formativas observadas num seminário católico}

De modo semelhante à estratégia utilizada por Goffman (1987), realizamos visitas de observação participante para estudar o mundo social dos seminaristas internados no estabelecimento seminário católico, buscando detectar a produção de subjetividade no contexto institucional. Produzimos um relatório descrevendo 20 visitas ao seminário. A partir das visitas semanais de observação, nas quais passávamos o dia com os seminaristas, partilhando sua rotina dentro da instituição, podemos afirmar que o seminário pesquisado se enquadra na categoria de instituição total elaborado por Goffman (1987, p. 11) : "um local de residência e de trabalho onde um grande número de indivíduos com situação semelhante, separados da sociedade mais ampla por um período considerável de tempo, levam uma vida fechada e formalmente administrada" . O seminário é um estabelecimento destinado a servir como local de instrução para os seminaristas, preparando-os para o sacerdócio católico.

Procuramos reconstruir os primeiros dias de funcionamento do seminário, no início do ano letivo, por meio de relatos dos seminaristas. Quando convocados para o início das atividades do estabelecimento, os seminaristas encontraram a vida no seminário organizada pela equipe dirigente: os novatos foram designados para a ocupação dos quartos e receberam um número cada, com o qual deveriam marcar suas roupas, além das chaves para entrar e sair do estabelecimento. Em seguida, numa assembléia, outros aspectos da vida do grupo na instituição foram formalmente organizados: os seminaristas receberam um caderno contendo orientações quanto à vida na instituição: "Regimento Interno", "Horário da Casa", "Organograma do Seminário", "Regimento Acadêmico", a "Grade Curricular do curso de Filosofia" e "Calendário para o 
ano letivo". Esses instrumentos não foram objeto de discussão na assembléia, sendo outorgados pelos formadores aos seminaristas, caracterizando-se a organização administrativa e burocrática do seminário.

Além desses elementos da organização formal da vida no contexto institucional, foi organizada também uma "Lista de Serviços da Casa", por meio de um sorteio, na qual todos os membros da comunidade assumiram alguma responsabilidade nas atividades de limpeza, manutenção e serviços domésticos. Os formadores também apresentaram, já confeccionada, uma lista das "equipes de cozinha", na qual os seminaristas formam grupos encarregados de lavar a louça usada nas refeições e de limpar o refeitório.

Aos seminaristas foram ainda apresentadas a realização periódica de "Convivências", que seriam dias de palestras formativas e de integração da comunidade. Um outro instrumento solicitado aos seminaristas foi a elaboração de um "Projeto de Vida Pessoal", no qual deveriam apresentar uma proposta personalizada de como pretendiam assumir a tarefa formativa durante o ano. Os seminaristas receberam também uma série de orientações e normas práticas sobre o que fazer, como e onde fazer, bem como proibições e admoestações. Cada fase da atividade diária do internado é realizada na companhia imediata de um grupo relativamente grande de pessoas, todas tratadas da mesma forma e obrigadas a fazer as coisas em conjunto.

Podemos perceber como todas as atividades foram rigorosamente estabelecidas em horários contínuos, de modo que uma leva à outra e toda seqüência de atividades é imposta de cima, por um sistema de regras explícitas e pelo grupo dirigente, constituído pela equipe dos formadores. As várias atividades obrigatórias foram reunidas num plano racional e único, supostamente planejado para atender aos objetivos oficiais da instituição. Há um controle de muitas das necessidades humanas pela organização burocrática do grupo dos seminaristas internados.

O controle e a vigilância sobre o conjunto dos internados, sob a responsabilidade da equipe de formadores, faz com que todos cumpram as normas estabelecidas e, ao mesmo tempo, salienta a infração de um indivíduo no contexto global da obediência visível e constantemente examinada dos demais. Verificamos que existe uma divisão básica entre um grande grupo controlado (os seminaristas internados) e uma pequena equipe dirigente (os formadores) 
que o supervisiona. $\mathrm{O}$ grupo dos internados vive na instituição e têm um contato restrito com o mundo externo.

Constatamos também que, no seminário, cada um desses grupos tende a conceber o outro por meio de estereótipos limitados e, até mesmo, hostis. Os internados podem ver os dirigentes como autoritários, condescendentes, arbitrários e mesquinhos. Os dirigentes vêem os internados como eternos insatisfeitos, reservados e talvez suspeitos. Os primeiros tendem, pelo menos sob alguns aspectos, a se sentirem inferiores, fracos e censuráveis. Os segundos costumam se sentir superiores e corretos. A mobilidade entre os dois estratos tende a ser superada ao longo do tempo, pois o seminarista é alguém que se prepara para o sacerdócio e poderá, então, fazer parte da equipe dirigente. Há também restrição de informações, sobretudo as relativas aos relatórios periódicos que os formadores preparam e enviam para os bispos responsáveis, informando sobre o desempenho de cada seminarista no processo formativo. Assim, desenvolvem-se dois mundos sociais e culturais diferentes, que caminham juntos com pontos de contato oficiais, mas com pouca interpenetração.

O trabalho no seminário, onde os seminaristas internados têm o atendimento de todas as suas necessidades planejadas, apresenta características peculiares. Como não há pagamento em dinheiro, mediação usual utilizada no mundo externo, há uma fraca motivação para executar o trabalho, para gastar mais ou menos tempo no seu término. O trabalho é considerado uma forma de o seminarista colaborar com a economia da instituição, além de ser um treino da humildade em realizar serviços simples. Ele contribui para o funcionamento da instituição, mas não é essencial.

\section{O mundo da equipe de formadores no seminário}

De acordo com Goffman (1987, pp. 69-70), de um modo geral, as instituições totais funcionam como um depósito de internados, mas elas se apresentam ao público como organizações racionais, planejadas de modo consciente como máquinas eficientes para atingir determinados objetivos e capazes de cumprir certas finalidades oficialmente declaradas. Um de seus objetivos oficiais mais amplos e freqüentes é a reeducação dos internados na direção de algum padrão ideal. São verdadeiras máquinas de sobrecodificação da subje- 
tividade. A contradição entre os objetivos oficiais confessados e aquilo que o estabelecimento realmente produz constitui-se no contexto básico do trabalho cotidiano da equipe dirigente (Goffman, 1987; Costa-Rosa, 2000, 2002).

A equipe de formadores procura alcançar os objetivos oficiais de preparar futuros sacerdotes para a renovação dos quadros da hierarquia da Igreja Católica, mas o funcionamento concreto do estabelecimento seminário está marcado por contradições entre práticas e discursos que se colocam como obstáculos e impedem a sua realização. $\mathrm{O}$ trabalho da equipe de formadores se reduz à administração, gerenciamento e controle dos seminaristas. Como material de trabalho, as pessoas podem também ser reduzidas às características de objetos inanimados, podendo ser vistas apenas em seus aspectos físicos. Um indivíduo pode ser etiquetado como um produto, numerado, encaixado numa nosografia, inscrito e descrito em relatórios e prontuários que dizem o que foi feito por ele, com ele e quais foram os responsáveis. Seu registro de caso vai crescendo à medida em que vão sendo acrescentadas notas e pareceres da equipe dirigente (Foucault, 1999a; Goffman, 1987).

Acreditamos que o trabalho da equipe dos formadores na administração dos seminaristas internados acaba por criar uma distância entre ambos os grupos, havendo mesmo uma certa "coisificação" dos internados, o que permite que a equipe de formadores possa governá-los, tomando inclusive medidas impopulares ou claramente repressivas. As instituições totais mantêm padrões tecnicamente desnecessários de tratamento em seus cuidados com o material humano. Isso se aplica ao alto padrão de vida que constatamos no seminário. Podemos dizer que os formadores se sentem responsáveis pelos seminaristas e procuram manter padrões humanitários com relação aos internados; trata-se de uma garantia que lhes oferecem em troca de sua liberdade.

Os seminaristas internados costumam ter um status e relações no mundo externo e o seminário precisa respeitar alguns dos direitos dos internados como pessoas. Diferentemente de outros internados em instituições totais, os seminaristas não perdem seus direitos civis e, portanto, não é preciso dar conta de uma papelada burocrática como a que exige a interdição de um indivíduo internado num hospital psiquiátrico e a transferência de seus direitos e deveres para a tutela de outra pessoa, que se torna responsável e seu representante legal. Os vínculos do seminarista com sua diocese e o seminário são informais, não 
possuem qualquer efeito legal. No seminário, procura-se valorizar o contato do seminarista com sua família, as atividades pastorais dos fins de semana, as tardes livres para saídas e o acesso aos meios de comunicação social mantêm os seminaristas em contato com o mundo externo.

As instituições totais funcionam mais ou menos como um Estado e sua equipe dirigente tem que enfrentar problemas de um modo parecido aos que têm os governantes de Estados (Goffman, 1987, p. 72), deparando-se com dilemas clássicos, como por exemplo: conflitos entre meios e fins, manutenção de padrões humanitários versus eficiência institucional, esforços para evitar fugas, esconder decisões quanto ao destino dos internados, distância versus afeição pelos internados e outras dificuldades específicas no trabalho com pessoas.

As pessoas, diferentemente de outros materiais de trabalho, podem receber instruções e executá-las sozinhas, mediante o uso de ameaça, prêmio ou persuasão. Mas se os seminaristas internados têm capacidade para perceber e seguir os planos da equipe de formadores, também podem opor-se veladamente a estes. A equipe dirigente tem que estar preparada para evitar os esforços organizados para fugas e tentativas de enganá-la ou de dirigi-la.

Vejamos alguns exemplos da equipe de formadores do seminário exercendo seu papel de governante:

a) No início do ano letivo, reunidos os seminaristas em assembléia, a equipe de formadores lhes apresentou oficialmente a forma de organização administrativa e burocrática do seminário:

$\mathrm{Na}$ assembléia, os formadores entregaram o caderno do seminário com orientações quanto à vida de comunidade do estabelecimento, incluindo as "Normas internas a serem seguidas pelos seminaristas", o Horário da Casa, o Regimento Acadêmico, Grade Curricular do curso de Filosofia e o Calendário para o Ano Letivo.... Os formadores entregaram o Horário da Casa para o presente ano aos seminaristas. Esse horário foi planejado pela equipe dos padres formadores, junto com o diretor de estudos do seminário e não foi objeto de discussões por parte dos seminaristas.... No rodapé da página onde foi impresso o Horário da Casa está escrito: "O seminário será melhor se você for 
melhor." "Entre vocês não será assim." (Mt 20,26) "Não vos ajusteis a este mundo, e sim transformai-vos com uma mentalidade nova para discernir a vontade de Deus, o que é bom, aceitável e perfeito." (Rm 12,2). Foi organizada também a Lista de Serviços da casa, por meio de sorteio, na qual todos os membros da comunidade assumiram alguma responsabilidade nas atividades de limpeza, manutenção e serviços gerais. $O$ "trabalho" é realizado duas vezes por semana, à tarde, nas segundas e quintas-feiras.... O padre reitor apresentou a programação da "Convivência", prevista para os próximos dias e escolheu-se uma equipe de liturgia encarregada das celebrações desses primeiros dias, até que o seminário inicie seu funcionamento ordinário.... Em seguida, o reitor explicou sobre a necessidade da elaboração de um "Projeto de Vida Pessoal" a ser entregue dentro de duas semanas e comentou algumas mudanças efetuadas no Horário da Casa, com relação ao ano anterior; enfatizou a importância e a obrigatoriedade da participação na missa diária; recomendou discrição no uso do telefone semi-público; falou das saídas controladas, de que é necessário pedir permissão aos formadores para se ausentar da casa fora dos horários já estabelecidos; pediu empenho e aplicação na execução dos trabalhos, pois trata-se de colaborar com a economia da casa, além de ser um treino da humildade em realizar serviços simples; finalmente, proibiu a entrada de pessoas não autorizadas na despensa... O padre reitor, juntamente com o padre diretor espiritual e o vice-reitor entregaram aos seminaristas uma folha na qual estava o "Organograma do Projeto Educativo do Seminário Católico" (Anexo 3), estabelecendo "canais de participação" e cujo lema é: "Educar para a liberdade, responsabilidade e maturidade”... O organograma termina com a seguinte frase: "Somos todos responsáveis por tudo e por todos e eu mais do que todos". O padre reitor insistiu muito na importância de uma atividade colegiada dos formadores, num diálogo permanente, na participação e empenho de todos para que o objetivo de formar futuros padres seja alcançado.

(Primeiros dias de funcionamento do seminário no início do ano letivo).

b) O reitor emite um relatório semestral sobre cada seminarista para o bispo respectivo, realizando uma entrevista com eles e procurando verificar seu desempenho nas várias dimensões do processo formativo: 
Havia um seminarista no computador conectado na Internet e outros dois lendo jornais. Sentei-me e peguei uma revista. Um dos rapazes me disse: "Você já soube da Avaliação Pessoal que o reitor solicitou que a gente fizesse agora no final do semestre, para levar na entrevista que teremos com ele?" Eu disse que não sabia de nada e perguntei: "Será que eu posso ver como é essa avaliação?" Ele consentiu e abrindo sua pasta, me passou uma folha impressa, que transcrevo a seguir:

Avaliação pessoal - pontos para reflexão

\section{Aspecto vocacional}

Qual é sua maior motivação para a vida sacerdotal? Você procura conservar e alimentar tal motivação? Acha que seus motivos vocacionais são realmente sérios, maduros e suficientes para uma vida sacerdotal futura? Caso contrário, procura descobrir motivações sempre mais profundas?

\section{Situação individual}

Pessoalmente você se sente bem ou está vivendo algum problema, alguma dificuldade que o angustia e impede de fazer uma caminhada saudável, de sentir-se tranqüilo e satisfeito consigo mesmo? Sua vida humano-afetiva é bem integrada? O aspecto da sexualidade é vivido de maneira bastante equilibrada e normal ou encontra algum desvio, alguma tendência negativa ou qualquer outra dificuldade nesse sentido, seja de caráter homo ou heterossexual? Se você tem algum problema de qualquer espécie, procura alguém para conversar, o Diretor Espiritual escolhido por você e aprovado pelo Bispo, ou vai escolhê-lo ainda? Aceitaria o próprio Diretor Espiritual, oferecido pelo seminário?

\section{Relacionamento com os demais}

A vida espiritual, em sentido amplo, é a vivência da fé na caridade e isso deve acontecer com todos os aspectos da vida de cada dia. Você percebe isso no relacionamento com os outros, numa atitude de amor e respeito para com os colegas, formadores, professores e funcionários? Procura contribuir para um bom clima de convivência entre todos, evitando atitudes não evangélicas, que desunem, distanciam, criam barreiras? Acima de tudo, se esforça para promover tudo aquilo que leva à concórdia, à paz, à comunhão, ao crescimento de todos e à edificação da comunidade? 
4. Vida de oração e outras práticas de piedade

Como cristão e seminarista, você se nutre dos meios de santificação, como a participação nas missas, terços, meditações, horas santas, celebrações penitenciais, vias-sacras, enfim, daqueles meios que ajudem no crescimento da vida cristã? Reza também individualmente? Procura fazer com que sua participação nesses momentos seja consciente e proveitosa para sua vida, evitando atitudes mecânicas e rotineiras? Alimenta também sua vida de fé com a meditação de leituras espirituais?

\section{Dimensão intelectual}

Você valoriza sua formação intelectual? Entende que a formação acadêmica ao lado dos demais aspectos formativos, irá lhe ajudar no seu futuro trabalho apostólico para liderar e dirigir bem uma comunidade, bem como evangelizar melhor? Assim, aproveita bem tudo o que o seminário the oferece em termos acadêmicos com boa participação em empenho nas aulas e aplicação nos estudos, bem como leituras de complementação e aprofundamento nas disciplinas? Faz bom uso do tempo disponível? Se realiza trabalhos pastorais nos finais de semana, estes não tomam seu tempo de estudo? Permite um equilíbrio entre a formação acadêmica e outras dimensões da formação?

\section{Dimensão pastoral}

Você acha que com seu trabalho pastoral está contribuindo realmente para a evangelização da comunidade onde você atua? Porquê? Você procura oferecer trabalhos importantes e diferentes daqueles que qualquer outro leigo poderia fazer ou simplesmente faz o que qualquer uma outra pessoa da comunidade poderia muito bem realizar? Você já pensou na possibilidade de preparar novos agentes de pastoral ou capacitar ainda mais os antigos com formação catequética, bíblica, litúrgica através de cursos de preparação? Você, por outro lado, acha que a pastoral está lhe ajudando, está contribuindo para sua formação? Porquê ou em quê, por exemplo? Acredita que o trabalho pastoral possa estar tomando tempo indevido de sua formação? Em que o seminário poderia ajudar para que se possa ter uma melhor atuação no trabalho pastoral? 


\section{Outras atividades formativas}

Na sua vida de estudo, trabalho e lazer você se aplica devidamente? Leva a sério seus deveres nesses aspectos, aproveitando bem as oportunidades para enriquecer bastante a sua formação cultural e humana? Procura participar e viver intensamente esses e outros aspectos da formação? Você procura ser uma pessoa aberta, disponível, dedicada e serviçal, num espírito de colaboração, ajudando na construção da vida comunitária e nas necessidades da casa ou alguém simplesmente voltado para si mesmo e para seus interesses particulares? Enfim, procura se preparar seriamente para uma vida sacerdotal bastante rica e significativa para o crescimento e a edificação do Povo de Deus? Tem consciência de tudo isso para seu futuro ministério?

Depois de ler a folha, perguntei: "O que vocês acharam dessa Avaliação Pessoal?" O rapaz sorriu e disse: "Pra ser sincero, a gente não gostou não. O reitor vai preparar um relatório para os bispos a partir dessa entrevista e esse relatório é decisivo para nossa permanência ou não no seminário".

Eu: "Você falou em sinceridade. Dá pra ser realmente sincero com o reitor ao responder essas perguntas?" O rapaz me olhou maroto e rindo disse: "Só se a gente quiser ser mandado embora mesmo".

Eu: "O que é que vocês vão fazer então?" Ele: "O de sempre, a gente vai dizer pra ele o que ele quer ouvir, ora essa! Aí fica tudo bem”. (20. Visita de observação).

Desde logo, neste inventário, o tema da sexualidade do seminarista é uma questão fundamental para sua permanência no estabelecimento e sucesso no processo formativo. Ingenuamente, busca-se verificar sua adesão à proposta formativa eclesiástica oferecida pelo seminário. O instrumento encontra um grande obstáculo: como ser transparente numa instituição totalitária? Não podemos deixar de pensar que o próprio roteiro funciona como um operador microfísico de exame, vigilância e sanção normalizadora para os seminaristas. Eles reagem estrategicamente: se não é possível ser o que a instituição quer, pelo menos é preciso parecer, adotando um discurso orientado de acordo com a pauta indicada. 


\section{Cartografias do seminário católico}

Encontramos no convento católico a matriz original das instituições totais (Benelli, 2003c). Há muito de conventual no seminário que pesquisamos. Mas trata-se de um convento colonizado por diversas estratégias disciplinares que visam à produção do sacerdote católico. Nesse sentido, procuramos detectar quais são os diversos atravessamentos institucionais que podem ser encontrados na constituição do seminário e de suas funções, estabelecendo paralelos entre ele e o hospital geral, o manicômio, a prisão e o colégio interno. Práticas de enclaustramento, isolamento, reeducação pedagógica, terapeutização da pedagogia, vigilância, controle, punição, premiação, promoção e controle podem ser ali verificadas mais ou menos em estado bruto.

Investigamos as origens históricas da instituição seminário e verificamos que seu aparecimento coincide com a constituição da sociedade disciplinar amplamente estudada por Foucault (1999a). Poderíamos afirmar que o seminário que investigamos é muito mais "foucaultiano" do que podem supor os seus diversos atores institucionais, no sentido de que "eles não sabem o que fazem" e também não "calculam os efeitos de suas práticas".

O seminário católico é um estabelecimento que visa à formação de sacerdotes, de padres para a manutenção dos quadros hierárquicos da Igreja católica, encarregados do serviço pastoral, profético e sacramental à comunidade católica. Em seus estatutos e regimentos, este estabelecimento oferece uma formação que se divide em seis campos: a vida comunitária, a dimensão humano-afetiva, a formação espiritual, a dimensão intelectual, a formação pastoral e a dimensão vocacional. Este é o projeto institucional oficial do seminário (Conferência Nacional dos Bispos do Brasil, 1995; João Paulo II, 1992).

Mas estudando o seminário católico, detectamos uma série de procedimentos utilizados pelo estabelecimento na formação dos candidatos ao sacerdócio. A vida comunitária implica a reclusão no claustro do seminário e, aparentemente, o próprio estabelecimento é considerado um instrumento formativo em si mesmo, com monitoração das saídas e ausências; considera-se que viver na instituição forma o seminarista. A convivência é tensa, caracterizada pelos diversos fenômenos típicos do enclaustramento totalitário (Goffman, 1987; Foucault, 1999b). 
Os relatórios semestrais de avaliação do processo vocacional de cada seminarista são percebidos como um instrumento de controle nas mãos dos formadores. O relatório confeccionado pelo reitor juntamente com os demais membros da equipe dirigente é um poderoso e efetivo instrumento da tecnologia microfísica que concentra os três elementos básicos que constituem o poder disciplinar: é um amálgama da vigilância escalonada e hierárquica, da sanção normalizadora e do exame. Seus efeitos visam à normatização e uniformização disciplinar do seminarista como um eu ideal.

Para confeccionar tal relatório, a equipe dirigente utiliza-se básica e principalmente da observação do comportamento e da conduta visível do seminarista. Estão previstas entrevistas-interrogatórios semestrais, raros e escassos encontros formais entre formadores e seminaristas, nos quais os primeiros exigem transparência e abertura dos formandos. Os seminaristas podem conhecer ou não o conteúdo do relatório a seu respeito. Isso não é um direito que possam exigir, mas é uma concessão generosa por parte da equipe dirigente, quando ocorre.

Os bispos, de posse dos relatórios, entrevistam, interrogam e admoestam os respectivos seminaristas quanto ao seu desempenho no processo formativo. O boletim de notas escolares também é conferido e utilizado como parâmetro de avaliação. Como são os bispos que pagam a formação, recebida gratuitamente pelos seminaristas, desejam ver seus investimentos bem aproveitados. A equipe de formadores desempenha claramente o papel de interditor/promotor dos seminaristas no processo formativo. Um bom relatório é condição indispensável para a permanência na instituição e prosseguimento nas diversas e graduadas etapas da formação, rumo ao sacerdócio.

Podemos, portanto, considerar o seminário católico como uma instituição tipicamente disciplinar cujo principal mecanismo e operador microfísico é o relatório, instrumento de efeitos ambíguos, parâmetro de normalidade, "vocacionalidade" e de produção dos duplos "anormais" da figura do seminarista: o jovem assexuado reprimido, o homossexual, o beato perverso. Os demais "complementos" formativos de ordem pedagógica e psicológica acabam funcionando como uma cobertura que se sobrepõe a esta tecnologia disciplinar, produzindo efeitos pouco consistentes no cotidiano institucional. Os seminaristas permanecem em contato com seus colegas e formadores, expostos a uma 
observação constante, o que Goffman (1987) denomina como exposições contaminadoras físicas, sociais e psicológicas. O "circuito", técnica de vigilância, promove a interligação de todas as esferas da vida do seminarista no contexto institucional, monitorando-as e avaliando a "vocação autêntica" do candidato por meio da sua conduta.

Constatamos outros elementos específicos de uma tecnologia disciplinar funcionando efetivamente no seminário: a tiranização, produtora de infantilização social, por exemplo, por meio da obrigação de pedir permissão; o processo de arregimentação, que se expressa na obrigação de executar a atividade regulada em uníssono com grupos de outros seminaristas; a campainha onipresente; o sistema de autoridade escalonada na qual padres formadores, professores, colegas, todos vigiam a todos; o sistema de privilégios, que inclui a graduação em Filosofia, alto padrão de vida oferecido pelo estabelecimento, que parece produzir um desclassamento e aburguesamento nos seminaristas e os dias livres para saídas do seminário; uma relação de tutela informal e cobertura incompleta das necessidades dos seminaristas, com o alívio de responsabilidades econômicas e a exigência de dedicação exclusiva à formação para o sacerdócio; processos de desligamento secretos e sumários de seminaristas do estabelecimento. Esses procedimentos não estão previstos, dessa forma, nos objetivos oficiais (Conferência Nacional dos Bispos do Brasil, 1995; João Paulo II, 1992). Eles foram detectados quando olhamos para as práticas cotidianas desenvolvidas no contexto institucional; podemos dizer que eles são o que a instituição não diz, mas faz.

A vida no contexto institucional parece ter sua especificidade, para além ou à revelia dos objetivos oficiais dos formadores. A vida no claustro produz uma série de fenômenos entre os seminaristas, caracterizando o processo de confraternização (Goffman, 1987, p. 159), problemas de contaminação num contexto em que "o inferno são os outros", rivalidades, possibilidades de delação, gozação coletiva, divisão em grupos menores, panelinhas, casais. No seio da comunidade reina o conflito, a "guerra fria", a resistência velada dos seminaristas. Esses fenômenos são notoriamente conhecidos por todos os envolvidos e tacitamente ignorados, são voluntariamente desconhecidos, denegados. Este modo de lidar com o processo de confraternização não deixa de ser enigmático, senão sintomático. 
A fofoca e os boatos que surgem e circulam entre os seminaristas, nos diversos grupos primários de referência que se formam espontaneamente, parecem funcionar como a rede de vigilância hierárquica escalonada: todos se vigiam, se policiam, normalizando-se pessoalmente; vigiam e policiam os demais, normalizando-os. Os agentes da equipe de formadores não têm que fazer praticamente nada. A máquina vigilante funciona automaticamente, controlando a todos, espalhando "poder" em todos os sentidos e direções. "Fulano e sicrano saem muito juntos... devem ter um caso". "Parece que beltrano e fulano estão namorando". "Todo dia o nome do sicrano está no quadro que indica as saídas à rua". "Fulano de tal não vai à missa faz duas semanas". Comenta-se sobre detalhes da vida alheia à boca pequena nos pátios, corredores e grupinhos, tecendo a crônica institucional dos amores, traições, invejas, ausências, escapadelas, futricas, rivalidades. Palavras maldosas que envenenam, que destróem reputações, que produzem uma normalização cujo combustível é o medo, o terror da "foice que corta cabeças", expressão institucional que indica a expulsão, vergonha escandalosa.

A fofoca, expressão verbal da agressividade no cenário institucional, produz comportamentos corretos, participação responsável nas atividades, cumprimento pontual das tarefas e deveres. Os próprios grupos diocesanos elegem um seminarista como coordenador que assume o posto de um autêntico "reitorzinho", reproduzindo as mesmas relações autoritárias com seus pares, subordinados que se deixam governar, obedientes. O coordenador coloca indivíduos na berlinda nas reuniões quinzenais do grupo diocesano, chama seus membros à ordem, corrige-os em público, cobra explicações e critica comportamentos individuais que pareçam inadequados e prejudiciais para a boa imagem do grupo, pois “o critério de sobrevivência é cuidar da imagem”. Por isso, tais reuniões são desagradáveis, segundo os seminaristas. Trata-se assim de uma sociedade transparente, visível em cada um de seus componentes, onde "cada um, do lugar que ocupa possa ver o conjunto... que os olhares não encontrem mais obstáculos, que a opinião reine, a de cada um sobre cada um... cada camarada torna-se um vigia” (Foucault, 1999a, p. 215).

"Estar na mídia", ser alvo dos comentários dos membros da instituição, é algo percebido como perigoso pelos seminaristas, por isso devem apresentar uma fachada pública inatacável, ou então posicionar-se com firmeza 
diante da fofoca destrutiva dos "camaradas". A opinião se erige como instância de julgamento, visando a impedir, inclusive, que os seminaristas possam agir mal, pois se percebem envolvidos num campo de visibilidade total no qual a opinião dos colegas, seus olhares e discursos funcionam como um controle disciplinar normativo: o medo da opinião tende a impedi-los de realizarem comportamentos, gestos, atitudes, hábitos, discursos inadequados (quando e se o fazem, procuram ocultá-lo cuidadosamente).

Se as pessoas são vistas por um tipo de "olhar piramidal", imediato, coletivo e anônimo, temos aí a efetuação de um poder que se exerce simplesmente porque as coisas serão sabidas, descobertas. O seminário é descrito por seus habitantes como "bastidores" e "caixa de ressonância" da realidade eclesial. O olhar vigilante produz a interiorização, sem utilizar violências físicas, coações materiais. "Um olhar que vigia e que cada um, sentindo-o pesar sobre si, acabará por interiorizar, a ponto de observar a si mesmo" (Foucault, 1999a, p. 218). O seminário, portanto, se erige como um "aparelho de vigiar" (Foucault, 1999b, p. 145).

Notamos uma espécie de má-fé, de desconfiança tácita e recíproca entre os seminaristas, estes e a equipe de formadores, esta e os bispos responsáveis pelo estabelecimento, e vice-versa, nesses mesmos níveis. Parece que o seminário exemplifica bem a constituição "de um aparelho de desconfiança total e circulante, pois não existe ponto absoluto. A perfeição da vigilância é uma soma de malevolências". (Foucault, 1999a, p. 221).

O seminário é também um estabelecimento que, ao impor a lei do celibato compulsório aos candidatos ao sacerdócio, utiliza mecanismos aparentemente repressivos para controlar a sexualidade dos seminaristas, mas o que realmente faz é incitá-la, acaba por fomentá-la, ao proibi-la (Foucault, 1982). Ao encerrar os seminaristas como um grupo monossexuado no claustro totalitário, acaba por vê-la emergir perversa e polimorfa. Sobre a "formação humano-afetiva" (Conferência Nacional dos Bispos do Brasil, 1995), denominação asséptica da sexualidade no jargão eclesiástico, pouco se fala. Sobre sexo, há um enorme silêncio oficial. Educação para o celibato? Há apenas balbucios, ou enormes lacunas no discurso. Porém, se sobre isso não se fala, "isso" fala, numa intensificação dos afetos e dos corpos, num intenso erotismo que, passando pelo flerte, paquera, se configura eventualmente em relaciona- 
mentos, em "casos”, em prováveis namoros, na formação de casais apaixonados, em amores secretos, nem sempre discretos, platônicos ou intensamente carnais. Assim sendo, dentro dos muros do seminário católico, sob o interdito do celibato compulsório, encontramos o frescor do desejo e uma sexualidade fervilhante. Parece que a vida no claustro tende a produzir uma exacerbação, intensificação e passagens ao ato das possibilidades neuróticas e perversas dos jovens vocacionados.

O seminário é atravessado pelo poder disciplinar que predomina na sociedade moderna, encarnado no estabelecimento por meio de técnicas, procedimentos, estratégias, tecnologias produtivas que visam ao controle, adestramento e modelação dos corpos que ali são enclausurados. Não se trata de reprimi-los nem de pura e simplesmente mutilá-los, mas de agir sobre eles, produzindo sujeitos (Foucault, 1999b).

De acordo com Foucault (1982), o "bio-poder", no gerenciamento da vida, criou o dispositivo de sexualidade, elemento estratégico de organização da coletividade humana, produzindo efeitos de poder e saber, erigindo instituições para sua aplicação e difusão por todo o tecido social. Pensamos que a instituição social da Religião e a organização da Igreja Católica desempenharam um papel específico no controle e na produção da sexualidade humana tal como ela se configurou ao longo do tempo (Foucault, 1982, 1999a, 1999b). O estabelecimento seminário nos proporciona uma noção experimental desse processo.

O seminário católico, pesquisado desde a perspectiva de Goffman e Foucault, pode ser pensado como uma instituição típica das sociedades disciplinares. Sua técnica básica é o confinamento e seu modo de funcionamento se baseia na lógica do Panopticon (Foucault, 1984b, 1999a, 1999b): visibilidade, vigilância hierárquica, exame, sanção normalizadora.

Os processos de subjetivação que se produzem na instituição engendram sujeitos que procuram escapar aos saberes constituídos (teorias sobre a formação eclesiástica e pedagógica que produziram o objeto "seminarista") e aos poderes dominantes (práticas individualizantes, submetedoras, normatizantes). Os sujeitos que ali emergem parecem possuir uma "espontaneidade rebelde" (Deleuze, 1992, p. 217), são novos tipos de acontecimentos, evanescentes em sua desterrritorialização: corpos, carne sem nome, sem sexo específico, desejo em uma materialidade brutal, intensidades e instâncias que não se 
submetem à moral, aos deveres, ao poder, ao saber, distanciando-se e diferindo do que já deixaram de ser.

\section{O analisador institucional: a festa de "Halloween"}

Um analisador institucional é um dispositivo natural ou construído que propicia a explicitação dos conflitos institucionais e sua resolução. Trata-se de uma montagem que torna manifesta as forças que constituem a organização. Baremblitt (1998, p. 152) afirma que "um analisador natural é produzido espontaneamente pela própria vida histórico-social, libidinal e natural, como resultado de suas determinações e margem de liberdade".

Nesse sentido, um acontecimento institucional de grande importância na vida da comunidade nos chamou a atenção: tratava-se de uma festa à fantasia. Preparada com esmero e grande investimento de energia por parte de muitos seminaristas, ansiosamente esperada, constituía-se no ponto alto do ano para os rapazes. Nas festas, usualmente, muitas das restrições cotidianas são suspensas e reina um clima de abertura onde é possível liberar-se com espontaneidade.

Os seminaristas realizavam um autêntico "carnaval”, brecha para respirar da seriedade dos papéis desempenhados pelos diversos atores no contexto institucional do estabelecimento. O tema de "Halloween" era, obviamente, apenas um adequado pretexto: uma festa das bruxas permite um amplo espaço para o exercício da criatividade e expansividade dos seminaristas. O objetivo era a integração da comunidade por meio de um tempo de diversão com comida, bebida, música, dança e alegria.

Durante a festa, realizou-se também o "Oscar", uma satírica entrega de prêmios a diversos membros da comunidade, indicados à revelia pela equipe organizadora. O “Oscar" era um grande boneco de plástico, pintado de dourado, oferecido como prêmio para os ganhadores. Os seminaristas encarregados da organização escolhiam os indicados a partir de traços característicos pessoais, gafes, manias ou incidentes comunitários que marcaram determinados rapazes, tudo com fina ironia e muito bom humor. Preparada e divulgada a

lista de candidatos, havia votação secreta para a premiação. É claro que os 
padres formadores (inclusive e principalmente o reitor) não foram poupados da "gozação coletiva", tendo sido premiados nos dois anos consecutivos que assistimos ao evento. Os apresentadores, vestidos como um casal de atores famosos de Hollywood, falavam um inglês improvisado, divertidíssimo, com direito a tradução ao vivo.

$\mathrm{O}$ ambiente era cuidadosamente preparado. O refeitório tornou-se semelhante a um salão de baile com uma decoração apropriada: morcegos de papel no teto, melancias foram transformadas em "abóboras de halloween", com buracos para olhos, boca e vela aromática em seu interior, as cores eram fortes, pesadas, preto e roxo. Máquina de "gelo seco", música ambiente e som de discoteca completavam o ambiente. Os seminaristas se superavam em sua capacidade de organização, trabalho conjunto e criatividade. Na preparação da festa, não eram nada dependentes, infantis, desanimados, submetidos. Pelo contrário, mostravam-se capazes de auto-organização, responsabilidade e dedicação espontânea e incansável.

Como um autêntico analisador institucional, esta festa anual superava com folga a comemoração da festa da Páscoa, data maior dos católicos e também a do aniversário do estabelecimento. Ela surgiu espontaneamente como um dispositivo que nos parece explicitar eficazmente o conflito relativo à produção de subjetividade no contexto institucional do seminário católico e sua resolução: manifesta o jogo de forças, os desejos, interesses e fantasmas dos diversos atores institucionais. O seminário funciona como uma máquina para produzir uma "identidade sacerdotal" nos seminaristas, conforme se pode ler nos documentos oficiais o sentido dos enunciados: "plasmar", "formar", "modelar", "inculcar". Mas isso não cola, dizem os seminaristas, que resistem ao processo de sobrecodificação, de modelagem. Eles são espertos, capazes mesmo de nos ensinar que a questão identitária é apenas um jogo. Eles jogam, mas não colam no modelo. Talvez seja o modelo mesmo que não cole em sujeitos pós-modernos.

A "Festa de Halloween" é um baile de máscaras, de fantasias. Os seminaristas se fantasiavam: o refeitório decorado ficava cheio de curiosos tipos farsescos, pois ali circulavam "padres", "bispos", "frades franciscanos" improváveis, "dráculas", "monstros corcundas", "anjos" e diversos personagens "femininos", é claro, "freiras" inacreditáveis, "bruxas", "fadas". Havia também convidados de fora, pessoas de algum modo ligadas ao seminário, homens, 
mulheres, moças e rapazes. Alguns vieram a rigor para a ocasião. Os seminaristas, fantasiados ou não, se soltavam na pista de dança, no embalo das músicas correntes mais animadas, demonstrando conhecimento das coreografias que eram moda na televisão. Os "exus" ficavam no seu canto, sentados à mesa, tomando cerveja e reclamando da "baixaria" dos companheiros fantasiados, escandalizados com sua ousadia e barulho.

Os seminaristas são capazes de uma grande irreverência e autocrítica. Essa festa era um enigma para nós. Não podíamos entender como ela era possível, ali, no estabelecimento. Ficávamos presos no seu aspecto lúgubre, numa crítica à invasão cultural de mais um modismo americano. Ora, os seminaristas, sob o pretexto da festa, expressavam o modo do próprio processo de produção de subjetividade, jogando, divertindo-se com a seriedade das personagens do seu mundo clerical. Eles resistiam aos assaltos das estratégias dos poderes disciplinares e dos saberes subjetivantes, normalizadores, que pretendiam se apropriar de seus corpos e produzir uma subjetividade serializada.

$\mathrm{O}$ baile de fantasias revelava que os seminaristas reservavam uma resposta debochada, usavam inclusive da leveza do humor, indo até a grosseria da farsa, como contra-armadilha ao projeto sobrecodificador e a sua pesada seriedade, baseada no mal-humor e na coação pelo medo. Durante a festa, era a equipe de formadores que estava destituída de seu usual papel de mando, exposta ao riso e rindo junto com os seminaristas. A festa expressa a espantosa capacidade dos seminaristas de transmitir algo fundamental: uma mestria no afastamento de si mesmo, em devir outro, em rir de si, dos outros, revelando apenas e novamente uma máscara, não um rosto. Um seminarista fantasiado revela alguém que habita provisoriamente o núcleo vazio de um sujeito desprovido de toda interioridade, personalidade ou identidade, algo que respira e pulsa em sua plena processualidade, distante de qualquer microfascismo.

\section{A especificidade da subjetividade produzida no seminário pesquisado}

Acreditamos que, de fato, o seminário católico produz uma subjetividade diferenciada em seu contexto institucional. A institucionalização da vida do indivíduo produz um tipo de subjetividade específica, trabalhando na sua formação por meio de práticas sociais que incidem diretamente na sua cons- 
tituição subjetiva, mobilizando suas diversas possibilidades. O seminário católico pesquisado pode ser adequadamente entendido a partir da categoria de instituição total (Goffman, 1987) e nele encontramos muitos dos instrumentos que nesses estabelecimentos totalitários modelam a subjetividade dos internados (Benelli \& Costa-Rosa, 2002).

Constatamos que os relacionamentos dentro do grupo dos seminaristas internados são predominantemente conflitivos e obscuros, marcados pela rivalidade fraterna, chegando ao extremo das delações e perseguições pessoais. As relações entre o grupo dos seminaristas/internados com a equipe dirigente/ formadores são caracterizadas pela ambigüidade: o tipo de liderança exercido pela equipe de padres formadores se pretende democrático, participativo, colegial e com insistência num regime de transparência, mas esse discurso entra em xeque quando práticas nitidamente autoritárias de dominação e controle começam a funcionar, ocasionando tensões, desgastes, expulsões de membros da comunidade. O processo decisório está realmente nas mãos da equipe de formadores, que, apesar de sua boa vontade, geralmente se vê presa do modo de funcionamento próprio das instituições totalitárias.

A comunicação, como vimos a propósito das assembléias comunitárias, padece de interessantes fenômenos que já comentamos. Há todo um jogo de esconde-esconde entre os dois grupos principais no estabelecimento, seminaristas e equipe de formadores guardam segredos uns dos outros. Facções dentro do grupo dos seminaristas internados também ocultam informações e segredos uns dos outros. Podemos dizer que uma das formas predominantes de administração dos conflitos é sua negação, seu não reconhecimento.

A subjetividade do seminarista diocesano é construída por meio dos diferentes processos que descrevemos ao longo desta análise. Suspeitamos que o seminário não está utilizando instrumentos que, realmente, lhe permitiriam atingir seus objetivos. Parece que, de fato, a vida concreta no cotidiano do estabelecimento produz resultados contrários aos objetivos institucionais oficiais.

Partimos da hipótese de que o candidato à ordem sacerdotal renuncia, livremente, a importantes aspectos de sua vida corrente, ao ingressar no seminário: há perda de autonomia pessoal, da liberdade para ir e vir, agir e decidir, começando sua "carreira moral" (Goffman, 1987, p. 111) como internado, num processo caracterizado pela segregação, esquadrinhamento e uniformiza- 
ção normatizada. Agora podemos apontar alguns dos efeitos, na subjetividade do seminarista, da vida no contexto institucional do seminário católico: é retirado do mercado de trabalho e inserido numa vida tutelada e tiranizada que neles fomenta comportamentos de dependência excessiva, ao reduzi-los a uma condição de menoridade; o celibato compulsório interdita a sexualidade do seminarista, mas ele deve viver integrado num grande grupo monossexuado, exposto a todas as vicissitudes do polimorfo desejo humano; sobretudo, a contradição detectada entre um aparelho de dominação microfísica e o discurso ideológico que proclama "liberdade com responsabilidade e participação" parecem produzir uma modalização subjetiva nos seminaristas, que apresentam características marcadas pela clivagem e pela recusa.

Parece que as instituições totais, e o seminário, como uma delas, têm mesmo "razões" que a equipe dirigente, com seus objetivos oficiais, desconhece (Maduro, 1981), de modo que acabam produzindo indivíduos diferentes do que pretendiam. Estamos constatando que, provavelmente, são mais formadoras e modeladoras da subjetividade as práticas sociais reais que se desenvolvem na vida institucional, do que seus projetos oficiais.

Como os seminaristas reagem a práticas sociais que instrumentalizam sua formação no contexto institucional do seminário? Quais os efeitos desses procedimentos de modelagem da subjetividade nos seminaristas?

Por meio das entrevistas realizadas, entendemos que os seminaristas costumam sentir o enclaustramento como perda da liberdade; utilizam o quarto individual como refúgio e espaço de privacidade e autonomia pessoal; o alívio parcial e incompleto das necessidades econômicas dentro de uma relação de tutela informal, na qual não se pode trabalhar para obter dinheiro, expõe os seminaristas a situações humilhantes e paradoxais: sentem-se pressionados, pela gratuidade da sua vida na instituição, a responder com bom desempenho nas várias atividades formativas e esta cobrança produz uma sensação de inferioridade e pouca valia pessoal; o tempo é experimentado como rotineiro, bastante controlado e vigiado; desligamentos misteriosos de colegas produzem ansiedade, pânico, persecutoriedade e sentimento de ser descartável; lançam mão de ajustamentos secundários, por meio de ações que mostram sua resistência à modelagem subjetiva, e de diversos processos adaptativos (conversão, colonização, sobretudo a estratégia da "viração" e da dissimulação) para bur- 
lar o processo normatizador institucional ao qual estão submetidos; os seminaristas lidam com a informação de um modo denegatório e a fofoca parece ser o principal indicador desse mecanismo. A vida no contexto institucional pode ser experimentada pelos seminaristas como algo altamente aversivo, experiência que não se deseja mais repetir. A percepção da diferença entre o discurso oficial formativo e a prática concreta do aparelho repressivo parece corroer as bases da convivência comunitária, minando a confiança e a segurança dos seminaristas.

Os seminaristas expressam, em geral, com tons bastante agonísticos, os modos como neles repercutem as práticas institucionais e, sobretudo, a contradição nelas observada, com um certo imaginário do seminário como espécie de microparaíso e com o próprio discurso institucional oficial. Isso se manifesta na forma de angústia, crítica e autocrítica, rancor, revolta velada e, às vezes, declarada; somatizações e escotomização (percebo, mas esquecerei).

A partir de nossas análises, emerge a hipótese de que os seminaristas parecem viver um tempo e circunstâncias que devem, a priori, serem varridos da sua história e que, embora seja condição inevitável para sua ordenação sacerdotal, é, ao mesmo tempo, algo que se suporta, fundado na certeza de que será esquecido. Constatamos, nos seminaristas entrevistados, que a experiência desse tempo de formação vivido nesse seminário coexiste com a esperança redentora do recalque.

A equipe dirigente tende a se colocar no papel de interditor e vigia dos seminaristas; sente o peso e o desgaste de administrar a instituição e reclama dos seminaristas, considerando-os eternos insatisfeitos, melindrosos, ingratos, sempre fazendo pressão e desafiando os formadores, de modo mais ou menos velado. Reclama que os seminaristas são demasiado problemáticos, indóceis e se escondem, vivem no anonimato e distante dos formadores. Percebe que há um clima pesado na instituição, ocultado por uma fachada de bem-estar e tranqüilidade. Detecta que algo, no seminário, não funciona como devia, sobretudo porque os padres novos que ali se formaram têm apresentado problemas. Ela vê a instituição como algo que deve ser aperfeiçoado por meio de uma luta que conquiste melhores condições de formação para os seminaristas.

Se o objetivo do seminário é formar sacerdotes, trabalhando a subjetividade dos seminaristas internados por meio do processo formativo descrito 
no Regimento Interno, discurso oficial no qual figuram os objetivos da instituição, estamos constatando que são realmente mais formadoras e modeladoras da subjetividade dos seminaristas internados as práticas sociais que se desenvolvem no contexto institucional. As alterações que realmente ocorrem parecem não ser as desejadas pela equipe dirigente. Os seminaristas parecem se submeter e se deixar educar, mas se defendem da "reforma" normatizadora imposta, utilizando-se dos ajustamentos secundários, habituando-se a costumes contrários ao discurso formativo da instituição e, também, valendo-se da estratégia de "dançar conforme a música".

Acreditamos que o processo formativo oferecido pelo estabelecimento seminário, ao padecer das mazelas estruturais das instituições totais, apesar da sua especificidade e diferenças já apontadas, ao funcionar a partir de um dispositivo tipicamente disciplinar, segrega, esquadrinha e submete os seminaristas, que procuram resistir como podem ao processo. Entendemos que os efeitos repressivos desse aparelho institucional impedem que a formação oficialmente buscada seja alcançada.

O processo formativo no seminário filosófico não faz o que diz, ou se faz, faz de modo sofrível, segundo os seminaristas. Mas, pelo contrário, também faz o que não diz, e o faz muito bem. As várias dimensões do processo formativo são implementadas de modo pelo menos sofrível, produzindo efeitos e resultados com essa mesma consistência. Já o que se faz sem dizer parece operar com profundidade no processo formativo, implementando uma série de procedimentos "ocultos", "desconhecidos", não intencionais, mas extremamente eficazes. Essa "programação oculta" no funcionamento institucional não pode produzir os resultados que se esperaria dos objetivos oficiais. Desse ponto de vista, esses mecanismos "desconhecidos" produzem o que podem: sujeitos (de)formados, (des)educados na simulação, na hipocrisia, acostumados a rivalidades, delações, vinganças, demonstrando o que não são e escondendo o que realmente são. Aprendem a viver cindidos: "sou assim, mas me mostro do jeito que desejam me ver"; "rezo segundo seu catecismo, mas ocultamente adoro meus próprios deuses"; "danço conforme sua música, mas meu baile é outro"; "uso a máscara que você quiser". Terminam por acreditar que devem denegar a realidade e conviver com ela, viver "um faz de conta", sabendo que o que realmente importa é outra coisa. 
O processo formativo no seminário pesquisado busca normatizar os comportamentos, pensamentos e sentimentos dos seminaristas. A relação formativa entre a equipe dirigente e os seminaristas internados se apresenta plena de contradições. Por um lado, há um discurso que proclama a participação, a iniciativa, a "liberdade com responsabilidade", conjugadas com um chamado a que o seminarista assuma a tarefa formativa como uma responsabilidade pessoal no estabelecimento. Por outro lado, o seminarista se sente pressionado a se conformar com as normas, deve aderir e formar consenso ao redor do projeto eclesiástico proposto pela organização. Detectamos o funcionamento de controles autoritários, explícitos e implícitos no contexto institucional, além do controle exercido pelos pares. O ideal visado parece ser a internalização do controle: o autocontrole.

Acreditamos que o modo de funcionamento desse seminário católico, as práticas sociais desenvolvidas, para além do discurso formativo de caráter participativo, numa política contraditória, pode estar produzindo nos seminaristas internados comportamentos próximos do perverso. Os seminaristas se colocam no papel de vítimas impotentes diante de um aparelho repressivo, lançando mão do uso de mecanismos de defesa tipicamente perversos: a clivagem (coexistência no ego de duas atitudes diversas para com a realidade, ambas persistem e não se influenciam) e a recusa (não reconhecimento de uma realidade de percepção traumatizante). Aparentemente, as contradições internas no processo formativo desse seminário católico estudado estariam produzindo seminaristas com uma subjetividade caracterizada pelo cinismo, pela astúcia, agressividade e ambição.

Esse seminário católico, por seu irrevogável caráter de instituição total, parece deixar muito remotas as ações instituintes, tanto pela desvalorização como pela coerção de ações coletivas de contra-hegemonia. Nessas condições, parecem possíveis ações individuais ou coletivas fundadas na renegação clandestina da ordem ou ocorrências do ato perverso ou mesmo psicopático - fazer clandestinamente ações contra as normas da ordem institucional -, sustentando, ao mesmo tempo, a afirmação do respeito a ela, por meio, por exemplo, dos diversos ajustamentos secundários.

O seminário, funcionando a partir da lógica das instituições totalitárias, despoja o indivíduo de sua autonomia, responsabilidade, capacidade de 
reflexão crítica, procurando transformá-lo em massa dócil, moldável, obediente e submissa. Como opera por subtração, retira o vocacionado da vida civil corrente para torná-lo um "seminarista", personagem habitante de um mundo clerical. É preciso examinar constantemente o seminarista, que é considerado, tacitamente, como um transgressor em potencial: vindo das camadas populares, de onde é arrancado, deve, no processo formativo institucional, socializarse e identificar-se com o poder clerical dominante, alinhado com as forças hegemônicas sociais.

O seminarista é posicionado como o "súdito", aquele que deve obediência ao seu "Senhor", membro do clero, seu padre formador. Um dia, o seminarista será possivelmente ordenado padre, quando passará a ser "Senhor", constituído em autoridade e dignidade. Por ora, no seminário, ele é infantilizado e vive na contraditória situação de submissão e humilhação, sem poder questionar. O jovem candidato ao sacerdócio não pertence à classe social dominante, seja ela clerical ou mundana, mas será levado a pactuar com ela. Suas condições reais de classe são mantidas no processo formativo: submissão, dependência, menoridade tutelada, marginalidade institucional que exige vigilância permanente. Oprimidos nas suas condições de vida, tanto social quanto institucional no seminário, tornam-se opressores nas relações fraternas com seus pares. A passagem do "súdito" para o "Senhor", a partir da ordenação sacerdotal, parece uma conseqüência "natural" desse processo: oprimido/ opressor, súdito/Senhor. É como uma carta de baralho: duas figuras invertidas que constituem apenas uma e mesma personagem.

Embora haja uma série de "brechas" que aparentemente suavizam o caráter totalitário do seminário (a contínua possibilidade de deixar de ser seminarista, por uma decisão pessoal do jovem; as saídas para a cidade; as atividades pastorais fora da instituição etc.), tendemos a pensar que tais aspectos apenas tornam a estratégia disciplinar mais difusa, invisível e capilar. Onde quer que esteja, o seminarista é alvo de uma vigilância onipresente: dos pares, da comunidade mais ampla etc., de acordo com as análises de Benedetti (1999). A flexibilização pedagógica da "grande disciplina" (Libânio, 1984) parece mais um aperfeiçoamento da tecnologia disciplinar, apontando para a sofisticação de "sociedade de controle" (Deleuze, 1992). 
Esta pesquisa não pretende ser a denúncia nem um ataque a um seminário supostamente autoritário e repressor. Foucault nos ensinou que não podemos ingenuamente acreditar que é possível brandir o poder com nosso saber. Organizando coerentemente práticas, saberes e sujeitos, detectamos uma lógica totalitária como eixo microfísico e produtor de subjetividade no seminário. Procuramos realizar um diagnóstico institucional, destacando os aspectos totalitários e disciplinares do seminário católico. O seminário se constitui numa multiplicidade que o pensamento só consegue abarcar por meio de cortes e perspectivas. É verdade que o seminário não é apenas uma instituição totalitária e disciplinar, mas essa dimensão, que constatamos ser permanentemente negligenciada e denegada na realidade cotidiana institucional, merece destaque fundamental. Podemos dizer que o próprio seminário está implicado na produção dos males de que todos ali se queixam. Somente outras práticas, novos saberes e novas instituições, emergentes a partir de um novo paradigma, poderiam ser promotoras de inéditas relações sociais baseadas na solidariedade, na autodeterminação, na autoprodução de si e do mundo, num processo permanentemente instituinte.

Benelli, S. J. (2007). Catholic seminary and priesthood formation: a psychosocial study. Psicologia USP, 17(3), 145-182.

\begin{abstract}
In this reserch we did an institutional analyses, which aims is to examine the catholic ecclesiastical formation practices by means of institutional functioning from a catholic seminary and the register of the ecclesiastical knowledge, producer of a specific subjectivity pattern (future priests). By observing the everyday of that establishment, the semi-structured interviews with institution actors, the analyses of official documents of the catholic Ministry and relevant literature, we looked for understanding the formation relationship between priests responsible for the formation and seminarians concerning to a privileged and constitutive device of the seminary as an agent producer of subjectivity. Thus we come to the conclusion that the seminary focused can be considered as a common disciplinary institution, which maintains the report as its main mechanism and microphysics device (exam tool, surveillance and normal process sanction).

Index terms: Psychology and religion. Institutional analysis. Seminaries. Subjectivity. Seminarians. Catholicism.
\end{abstract}


Benelli, S. J. (2007). Le seminaire catholique et la formation sacerdotal: un étude psychosocial. Psicologia USP, 17(3), 145-182.

Résumé: Dans cette recherche nous accomplissons une analyse institutionnel, dont l'objective c'est de rendre problématique les practiques formatives ecclésiastiques catholiques, la manière comme eux se présentent dans les modes de fonctionnement institutionnel d'un séminaire catholique et dans le registre du savoir ecclésiastique, comme producteurs d'une modalité spécifique de la subjectivité(futures prêtes). A partir d'observation du cotidienne d'estabelissement, des entretiens demi-structurés avec differents auteurs institutionnels; $d^{\prime}$ anal yse des documents officiels du Magistère catholique et d'une révision bibliographique pertinent,nous cherchons comprendre dês relations de formation entre les prêtes formateurs et les séminaristes comme um dispositive privilegié de constitution du séminaire comme agence de production de la subjectivité. Nous avons conclu que le séminaire, sur quoi nous avons conduit une investigation,peut être consideré comme une institution disciplinaire, d'une manière typique,dont le mecanisme principal et l'operateur microphysique c'est le rapport(l'instrument d'examen, vigilance et sanction, qui rendre normal)

Mot-clés: Psychologie et Religion. Analyse institutionnel.Séminaires. Subjectivité. Séminaristes. Catholicisme.

\section{Referências}

Baremblitt, G. F. (1998). Compêndio de análise institucional e outras correntes: teoria e prática. Rio de Janeiro: Record.

Benedetti, L. R. (1999). O “novo clero": arcaico ou moderno? Revista Eclesiástica Brasileira, 59(233), 88-126.

Benelli, S. J. (2002). O internato escolar como instituição total: violência e subjetividade. Psicologia em Estudo, 7(2), 19-29.

Benelli, S. J. (2003a). Dispositivos disciplinares produtores de subjetividade na instituição total. Psicologia em Estudos, 8(2), 99-114.

Benelli, S. J. (2003b). O internato escolar "O Ateneu": produção de subjetividade na instituição total. Psicologia USP, 14(3), 133-170.

Benelli, S. J. (2003c). Pescadores de homens: a produção da subjetividade no contexto 


\section{O Seminário Católico e a Formação Sacerdotal: um Estudo Psicossocial}

institucional de um seminário católico. Dissertação de Mestrado, Faculdade de Ciências e Letras, Universidade Estadual Júlio de Mesquita Filho, Assis, SP.

Benelli, S. J. (2004). A instituição total como agência de produção de subjetividade na sociedade disciplinar. Estudos de Psicologia, 21(3), 237-252.

Benelli, S. J., \& Costa-Rosa, A. (2002). A produção da subjetividade no contexto institucional de um seminário católico. Estudos de Psicologia, 19(2), 37-58.

Benelli, S. J., \& Costa-Rosa, A. (2003). Geografia do poder em Goffman: vigilância e resistência, dominação e produção de subjetividade no hospital psiquiátrico. Estudos de Psicologia, 20(2), 35-49.

Beozzo, J. O. (1993). A igreja do Brasil: de João XXIII a João Paulo II, de Medellín a Santo Domingo. Petrópolis, RJ: Vozes.

Brandão, M. (1984). Psicologia e formação religiosa. São Paulo: Paulinas.

Conferência Nacional dos Bispos do Brasil. (1995). Formação dos presbíteros da igreja no Brasil: diretrizes básicas. São Paulo: Paulinas.

Costa-Rosa, A. (2000). O modo psicossocial: um paradigma das práticas substitutivas ao modo asilar. In P. D. C. Amarante (Org.), Ensaios de loucura e civilização (Vol. 1, pp. 141-168). Rio de Janeiro: Fiocruz.

Costa-Rosa, A. (2002). A instituição de saúde mental como dispositivo de produção de subjetividade. Faculdade de Ciências e Letras, Universidade Estadual Júlio de Mesquita Filho, Assis, SP. Texto não publicado.

Deleuze, G. (1992). Conversações (P. P. Pelpbart, trad.). Rio de Janeiro: Ed. 34.

Finkler, P. (1990). O formador e a formação (L. R. S. S. Malta, trad.). São Paulo: Paulinas.

Foucault, M. (1982). A vontade de saber (4a ed., M. T. C. Albuquerque, trad.) Rio de Janeiro: Graal.

Foucault, M. (1984a). O uso dos prazeres (M. T. C. Albuquerque, trad.). Rio de Janeiro: Graal.

Foucault, M. (1984b). A verdade e as formas jurídicas. Rio de Janeiro: Nau.

Foucault, M. (1985). O cuidado de si (M. T. C. Albuquerque, trad.). Rio de Janeiro: Graal.

Foucault, M. (1999a). Microfísica do poder (14a ed., R. Machado, org., trad.). Rio de Janeiro: Graal.

Foucault, M. (1999b). Vigiar e punir: nascimento da prisão (21a ed., R. Ramalhete, trad.). Petrópolis, RJ: Vozes.

Giordani, B. (1990). Resposta do homem ao chamado de Deus: estudo psicológico sobre a 
vocação (A. Cancian, trad.). São Paulo: Loyola.

Goffman, E. (1987). Manicômios, prisões e conventos (2a ed., D. M. Leite, trad.). São Paulo: Perspectiva.

Igreja Católica. (1982). Compêndio do Vaticano II: constituições, decretos, declarações. Petrópolis, RJ: Vozes.

Igreja Católica. (1983). Código de direito canônico (12a ed., Conferência Nacional dos Bispos do Brasil, trad.). São Paulo: Loyola.

Igreja Católica. (1992). Catecismo da Igreja Católica. (Conferência Nacional dos Bispos do Brasil, trad.). São Paulo: Loyola.

João Paulo II. (1992). Sobre a formação dos sacerdotes: pastores dabo vobis. São Paulo: Paulinas.

Lefèvre, F. (2000). O discurso do sujeito coletivo: uma nova abordagem metodológica em pesquisa qualitativa. Caxias do Sul, RS: EDUSC.

Libanio, J. B. (1984). A volta à grande disciplina. São Paulo: Loyola.

Maduro, O. (1981). Religião e luta de classes. Petrópolis, RJ: Vozes.

Moro, C. (1997). A formação presbiteral em comunhão para a comunhão: perspectivas para as casas de formação sacerdotal. Aparecida, SP: Santuário.

Recebido em: 1/02/2005

Aceito em: 15/08/2005 